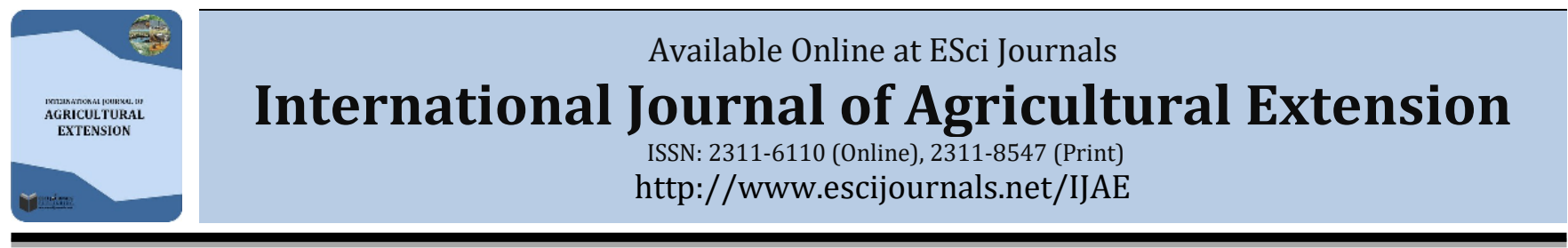

\title{
NEED ASSESSMENT OF FARMERS IN CROP-LIVESTOCK PRODUCTION SYSTEMS IN IDO LOCAL GOVERNMENT AREA, OYO STATE, NIGERIA
}

\author{
Sosina Adedayo \\ Department of Animal Science, University of Ibadan, Ibadan, Nigeria.
}

\section{A B S T R A C T}

Agricultural projects and programmes funded by governments and donor agencies often failed to achieve the desired set objective(s) at the system levels. The study tries to assess the existing production practices with a view of coming up with a consensus farmer need in a crop-livestock production system at Ido Local Government Area (LGA). The study used a three-stage-sampling technique to elicit information from 225 respondents. Ido Local Government Area was purposively selected for the study. Three cells were randomly selected for the research, three villages were randomly selected in each cell and twenty-five farmers were selected using the snowball selection technique. The data obtained from the Participatory Rural Appraisal were analyzed using descriptive statistics. The pairwise ranking tool helped in determining the importance of the identified problems from the FGD in the study area. The researcher identified the following problems $(\mathrm{Pb})$ from the focus group discussion; inadequate capital for livestock production (Pb1), poor housing for livestock (Pb2), inadequate nutrition for livestock ( $\mathrm{Pb} 3)$, diseases of crops (Pb4), livestock and predatory attack on crops (Pb5). The pairwise comparison of percentage of $\mathrm{Pb} 1$ versus (vs) $\mathrm{Pb} 2$ was $80 / 20 \%, \mathrm{~Pb} 1$ vs $\mathrm{Pb} 3$ was 68/32\%, $\mathrm{Pb} 1$ vs $\mathrm{Pb} 4$ was $80 / 20 \%, \mathrm{~Pb} 1$ vs $\mathrm{Pb} 5$ was $12 / 88 \%, \mathrm{~Pb} 2$ vs $\mathrm{Pb} 3$ was $68 / 32 \%, \mathrm{~Pb} 2$ vs $\mathrm{Pb} 4$ was 20/80\%, $\mathrm{Pb} 2$ vs $\mathrm{Pb} 5$ was $20 / 80 \%$, $\mathrm{Pb} 3$ vs $\mathrm{Pb} 4$ was $32 / 68 \%$, $\mathrm{Pb} 3$ vs $\mathrm{Pb} 5$ was $20 / 80 \%$, vs $\mathrm{Pb} 4$ vs $\mathrm{Pb} 5$ was $20 / 80 \%$ respectively. The ultimate farmers' problem in crop-livestock production systems (CLPS) that needs immediate intervention and technical assistance was inadequate capital as perceived from the responses of the farmers.

Keywords: Agricultural problems, Donor agencies, Interventions, Production systems.

\section{INTRODUCTION}

In Africa, the top-bottom approach has always been the bane of technological and economic underdevelopment. Most donor agencies, private, or government do not have sufficient information as to the needs of the farmers based on their locality before coming up to finance or recommend. The actual authors need of the project recipient is usually at variance with the information available to the donor agencies either private or government. Most agricultural programs and strategies do not have direct benefits to the needs and aspirations of the resource-poor at the system level. With the faulty background, many had reported in most cases, the poor agricultural project implementation (Adesina, 2010) or impact assessment of such policies leaves much to be desired (Lennie \& Thomas, 2005). Various authors

* Corresponding Author:

Email: dayososina@gmail.com

(C) 2019 ESci Journals Publishing. All rights reserved.
(Adesina, 2010; FAO, 2014) surmised that rather than the agricultural policies and programs trying to solve the farmer's problems, the programs targeted a few people making.

FAO (2015) conclude that the sustainability of such projects deficient. Against this backdrop, there should be an enabling platform for the donor agencies to operate before their policies can meet the farmer's expectation at the system level (IFAD, 2015). However, the World Bank (2015) reported that it is somewhat unfair to say that most international projects and donor agencies are not entirely successful especially in Africa. The CLPS is of grave importance not only because existing systems are expanding but also because former specialist livestock or crop production systems are diversifying into croplivestock (Thornton et al., 2002, Steinfeld et al., 2006). Considering their significance on the livelihood of the poor, proper understanding of crop-livestock production system is critically important to derive appropriate 
technology transfers and institutional reforms for poverty alleviation, food security, and sustainable resource management (Thornton \& Herrero, 2001).

The benefit of integrating crops and livestock has been understood and practiced by farmers for thousands of years (FAO, 2003). It is a known fact that farmers in the study area involve or practice an extensive or traditional system of management. They keep livestock in small numbers, giving less attention to housing, feeding, and health management. Consequently, the animals scavenge on roadside feeding on grassland and household waste as a supplement in a community where the majority of the population is involved in a crop-livestock farm in the Ibadan/Ibarapa zone of Oyo State (Babayemi et al., 2014).

This study aims to assess the existing production practices with a view of coming up with a consensus farmers need in a crop-livestock production system as a guide for the possible area of intervention at the system level in Ido LGA.

\section{MATERIALS AND METHODS}

The study was carried out in Ido LGA of Oyo State of Nigeria. The area is ethnically heterogeneous with a high concentration of smallholder crop and livestock farmers, considered as the occupational group with a high incidence of poverty. Secondary data obtained put the population of the study area at 81,115 out of which $52 \%$ are males while $48 \%$ are females.

The area lies within longitudes $1^{\circ} 5^{\prime} \mathrm{W}$ and $1^{\circ} 39^{\prime} \mathrm{W}$ and latitudes $7^{\circ} 9^{\prime} \mathrm{N}$ and $7^{\circ} 36^{\prime} \mathrm{N}$, covering an area of $1,782.2$ $\mathrm{km} 2$. It has a bimodal rainfall pattern ranging between 1200 and $1500 \mathrm{~mm}$ with a peak rainy season from April to August, and a minor rainy season from August to November.

The researcher collected data through the use of questionnaires at the focus group discussion which included the farmers' bio-data, household characteristics, the range of farm sizes, labor availability, seasonal patterns, types of animals raised by households, the purpose of raising animals', etc.

The study used a three-stage-sampling technique was to elicit information from 225 respondents. The researcher purposively selected the Ido Local Government Area for the study. From the eight cells making up the Local Government Area, the researcher randomly selected three cells for the research. Furthermore, the researcher purposively selected three villages in each cell and twenty-five farmers approached through the snowball technique from each village making two hundred and twenty-five farmers utilized for the study.

ILRI (2014) defined a nuclear family as one that eats together in a common pot or cooking point. The researcher chose this defined group by ILRI (2014) as a farming household. Consequently, the researcher invited 25 farming households to a half-day interactive session to discuss the constraints of crop-livestock production in the study area. The constraints militating against crop and livestock agricultural production were identified among farmers and listed for discussion in the PRA. The researcher used the PRA approach in carrying out the needs assessment of the invited crop-livestock farmers. PRA offers a robust discussion among the participants, with a view of charting a progressive way forward or finding a solution to a common problem or issue. PRA has two main components namely Focus Group Discussion (FGD) and structured questionnaire in which respondent farmers identify their common challenges confronting their farming systems. The pairwise ranking tool helped in determining the importance of the identified problems from the FGD in the study area and possible solutions proffered at the system level.

The researcher analyzed the data obtained from the Participatory Rural Appraisal using descriptive statistics (frequency distribution, means, percentages, pairwise ranking).

\section{RESULTS AND DISCUSSION}

In the simple and pairwise ranking technique, five constraints were identified by farmers in CLPS at Ido LGA of Oyo state. These constraints include; inadequate capital for livestock, poor housing for livestock, inadequate nutrition, diseases of crops and animals, and predator attacks that affect production.

The need assessment of respondent farmers in croplivestock production systems in Ido LGA: Table 1 shows the need assessment of respondent farmers involved in CLPS in Ido LGA that were analyzed using the simple ranking, pair-wise ranking and matrix scoring technique of the PRA. About ten (10) challenges confronting CLPS from FGD were itemized, only five (5) were agreed upon to be a priority to the FGD.

Data mentioned in the Table 1 shows the prioritized problems for Ido Local Government Area. Inadequate capital for livestock, poor housing for livestock, inadequate nutrition, diseases of crops and animals, predator attacks are recorded problems on rank 1, 2, 3, 4 and 5 respectively. 
Table 1. Pair wise comparison of problems at Ido area.

\begin{tabular}{lc}
\hline Comparison & More Important \\
\hline Problem 1 vs Problem 2 & 1 \\
Problem 1 vs Problem 3 & 1 \\
Problem 1 vs Problem 4 & 1 \\
Problem 1 vs Problem 5 & 1 \\
Problem 2 vs Problem 3 & 3 \\
Problem 2 vs Problem 4 & 4 \\
Problem 2 vs Problem 5 & 2 \\
Problem 3 vs Problem 4 & 4 \\
Problem 3 vs problem 5 & 5 \\
Problem 4 vs Problem 5 & 5
\end{tabular}

The FGD provided solutions to the challenges confronting the CLPS in Ido LGA as indicated in Table 2.

For inadequate capital for livestock production (Problem, Pb1): To the problem of inadequate capital for livestock production, the solution proffered by the FGD was the sourcing of funds from local finance houses, credit and thrift organizations and income generation from other sources like family members, friends, and associates. At the system level, there are various means by which farmers can also have access to soft loans to meet up with the various seasonal and time-bound agricultural operations.

To militate against default, farmers in the CLPS could guarantee each other as essential criteria for loan acquisition. Furthermore, the out-growers programme is a programme wherein the up-taker of a product will employ services of farmers in the production of farm produce mainly for up-taker after reaching a careful memorandum of understanding on the price, quality, and other necessary conditions. Livestock farmers can participate in the out-grower programme for poultry producers in which the programme provides feed and medication while the farmers' only responsibility is the provision of labor and security. In the out-growers scheme, out-grower and the investor share risk at a predetermined rate.

Table 2. The need assessment of Ido using PRA technique.

\begin{tabular}{|c|c|c|}
\hline Sr. No & Problems & Solutions \\
\hline$\overline{1 .}$ & Inadequate capital for livestock production & $\begin{array}{l}\text { Source for funds from finance houses, credit and thrift } \\
\text { organization and income generation from another sources }\end{array}$ \\
\hline 2 & Poor housing system for livestock & More training needed on improved housing system \\
\hline 3 & Inadequate nutrition & $\begin{array}{l}\text { Training on improvement in feeding using crop residue } \\
\text { and agro-industrial by-products }\end{array}$ \\
\hline 4 & Diseases of crop and animal & $\begin{array}{l}\text { Genetic improvement on disease resistance varieties of } \\
\text { crops and animals }\end{array}$ \\
\hline 5 & Predator attacks on crops and livestock & $\begin{array}{l}\text { Anti-snake drugs and chemicals should be made available } \\
\text { Proper method of hunting and trapping is needed }\end{array}$ \\
\hline
\end{tabular}

For poor housing for livestock (Problem, Pb2): The solution proffered to problem 2 from the FGD was the need for training on the area of improved housing systems for livestock. Research showed an alarming number of farm animal losses due to inadequate housing. Factors causing farm animal loss include theft, road accidents, diseases, inadequate nutrition, and pest. Consequently, all these defects on the animal production system have a cumulative effect on the economic losses to the farmers. Non-provision of good housing causes a reduction in production sustainability. Appropriate technology on affordable and improved housing system for livestock (with the use of available and inexpensive housing materials like bamboo, wooden poles and fairly used iron-roofing sheets) through the extension officers at the system level should be encouraged and intensified. During the rainy season, weather-related diseases like diarrhea, dysentery and other diseases like Peste-des-petits ruminante, principally caused by improper housing system leads to high mortality in the reared livestock.

For inadequate nutrition (Problem, Pb3): From the FGD, the solution proffered to inadequate nutrition was training on improved feeding technique using crop residue and agro-industrial by-products ruminants especially during the dry season. At the dry season, the quantity and quality of available forages reduced leading to loss of body weight on livestock. During this period, the farmers need to be taught (by village extension agents) the relevant feeding techniques on the use of 
abundant crop residue especially during and after harvest usually in the early dry season. These crops residue could serve as a vital feed supplement for ruminant residue cost of production and increase the body weight gain. Necessary also is the training of farmers on the chemical and physical treatment of crop residue and non-protein nitrogen (NPN) sources for ruminant feeding.

For diseases of crops and animals (Problem 4, Pb4): From the FGD, the solution proffered to the problem of crop and animal diseases was a genetic improvement on crops and animals that will resist the identified infections in the study area. Developing disease-resistant crop varieties through appropriate research that will improve crop production; thus arising from the farmers' feedback mechanism on the adoption of the technology developed by research institutions for farmers' adoption. Furthermore, intensive and continuous livestock breeding programmes through purposeful research aimed at enhancing the adaptation and productivity of hardy indigenous breeds that are resistant to diseases. Currently, there is a livestock development programme geared towards improving the housing of the indigenous dairy breeds (i.e., the White Fulani cattle) to increase their average daily milk production capacity per animal of 2-4 litters.

For the predator attack (Problem 5, Pb5): For the problem of predator attack identified through the FGD, the solution proffered was the use of appropriate agrochemicals to control the predators. However, there are strong reservations to the use of these agrochemicals chemicals and its hazard on humans as well as its usage as preservatives on farm produce preservation.

Farmers practice involves the use of agrochemical for crop production which has a residual effect and capable of causing diseases such as cancer in the final consumer. In solving this challenge, a conscious effort has been made to produce crops organically without the use of agrochemicals thereby eliminating any form of residual effect in humans after consumption.

\section{DISCUSSION}

The need assessment of respondent farmers in CPLS in Ido LGA: The following were the identified needs and solutions proffered by the respondent farmers from the FGD in the study area.

The need assessment of respondent farmers in Ido LGA revealed the high intensity of crop-livestock production systems. This production system practices agreed with the Sustainable Development Goal (SDG) (FAO, 2015) but in contrast to specialized industrial revolution agricultural practice opined in some quarters (Sere and Steinfold, 2006). Crop-livestock production systems can contribute to the Millennium Development Goals (MDGs) project (Lennie and Thomas, 2005). Adesina (2013) also agreed with the submission of inadequate capital for livestock production but in contrast with inadequate input for agricultural production reported in some African countries (FAO 2014). SDG in vision 2020 also recommended sourcing of funds from local finance houses, credit and thrift organizations including income generation from other sources, as a panacea to inadequate capital for production (FAO, 2015).

Sosina (2017) research posited the need for training on improved housing systems for livestock production for farmers while emphasizing the significant role of housing in ruminant management. Furthermore, Babayemi et al. (2014) while mapping feed resources in some rural farmers reiterated the importance of improved housing system to the indigenous breed in milk production. In addition, appropriate technology on an improved housing system for livestock using inexpensive local materials through the extension officers at the system level should be encouraged and intensified. This finding agreed with Oladeji \& Oyesola (2008) that reported the need for appropriate technology on small ruminant production among farmers at Iseyin LGA. Bolorunduro et al. (2004) also corroborated the view that poor housing system affects livestock production adversely while in contrast, Wassena et al. (2013) surmised feeding as the most critical production constraint to ruminant production.

Training on improved feeding technique using crop residues, crop waste and agro-industrial by-products for ruminant production especially during the dry season is essential. This finding agreed with Okunola et al. (2010) who reported the perception of farmers on livestock farming and ILRI (2018) that deduced from their results an increased performance of ram fed different inclusion of High-Quality Cassava Peel (HQCP) in compounded concentrate diet for ram fattening. Onyeonagu \& Njoku (2010) \& Bamigboye (2013) proposed the feed block processing technique as a panacea for ruminant feeding challenges, especially during the severe dry period. Moreover, the various methods for the preservation of forages (FAO, 2014) could be adopted by farmers in the study area. Farmers can use these tested methods as a 
solution to inadequate nutrition in ruminant production. Also identified as significant constraints was the control of crops and livestock diseases. The solution identified by researchers centred on genetic improvement leading to resistance by crops and animals to recognized diseases in the study area. Literature research showed that Sosina (2017), reported similar result on crop and livestock genetic improvement in Ibadan/Ibarapa zone of Oyo state, Nigeria. This view was in contrast with FAO (2003) submission that reported livestock fertility and crop fertilization as the constraint to crop and livestock production. Olaniyan (2015) reviewed new varieties of maize that can help provide the maize farmers betterinformed choices and adapt to the crop-livestock production systems in terms of average biomass productivity/yield. According to IFAD (2015), they posited instituting purposeful research aimed at livestock development that will enhance adaptation and productivity of indigenous breeds.

Predatory attacks on livestock and crops can be controlled either by biological, mechanical, or chemical methods. However, there is a need for continuous sensitization on the dangers associated with consuming predators killed because of chemically treated crops because of its residual effect on the consumer (FAO, 2015). Individuals who consume chemically treated crops or animals that consume treated crops are prone to health-related hazards such as cancer (FAO, 2014).

\section{CONCLUSION AND RECOMMENDATIONS}

In formulating policies and programmes for agricultural development in developing countries, it is necessary to assess the farmers' needs in a crop-livestock production system. Using this method serves as a guide for any technical assistance including indicating possible area(s) of intervention that helps programme and project implementers achieve the set objective(s) and support from the policy makers, government and international donor agencies towards leading to improved and sustainable agriculture.

\section{REFERENCES}

Adesina, A. A. (2010). Conditioning trends shaping the agricultural and rural landscape in Africa. Agricultural Economics, 41, 73-82.

Amole, T.A. \& A.A. Ayantunde. (2016). Assessment of Existing and Potential Feed Resources for Improving Livestock Productivity in Niger. International Journal of Agricultural Research, $11,40-55$
Babayemi, 0.J., A. Samireddypalle, A.O. Sosina, A. A. Ayantunde, I. Okike, \& A. J. Duncan. (2014). Characterization of farming and livestock production systems using the feed assessment tool (FEAST) in selected local government areas of Osun state, Nigeria. Research program on integrated systems for the humid tropics ILRI Technical Report, December 2014.

Bamigboye, F.O. (2013). On-farm use of feed-block for small ruminant production in Iwo LGA, Osun State, Nigeria. A Ph.D. Thesis submitted to the Department of Animal Science, University of Ibadan, Ibadan.

Bolorunduro, P.I, I.E.J. Iwuanyanwu, S.O. Aribido \& A.O.K. Adesehinwa. (2004). Effectiveness of extension dissemination approaches and adoption levels of livestock and fisheries technologies in Nigeria Food, Agriculture and Environment, 2(1), 298302.

FAO. (2003). Fertilizer and the future. IFA/FAO Agriculture Conference on Global food security and the role of Sustainability Fertilization. Rome, Italy. 16th-20thMarch, 2003, pp 1-2.

FAO. (2014). Crop Residues and Agro-Industrial byProducts in West Africa: Situation and Way Forward for Livestock Production. FAO, Rome, Italy, p64.

FAO. (2015). The state of food and agriculture: social protection and agriculture: breaking the cycle of rural poverty. FAO publication.

IFAD. (2015). State of Food Insecurity in the World 2015. Meeting the 2015 Int. Hunger targets: taking stock of uneven progress. Rome, FAO.

International Livestock Research Institute (2018). Performance and economic returns of ram fed different inclusion of High-Quality Cassava Peel in compounded concentrate diets for ram fattening; Workshop poster presented at the House of Chiefs, Secretariats, Agodi, Ibadan, 13th December 2018.

Lenné, J. M., \& D. Thomas. (2005). Identifying Options to Reduce Poverty and Enhance the Livelihoods of Small-Scale Crop-Livestock Producers in SubSaharan Africa, Output Report from R8444 for the DFID Crop Protection and Livestock Production programmes, Aylesford, Website: www.cpp.uk.com

Okunola, O.O., A.J. Amuda \& F.M. Ayanwamide. (2010). 
Farmers' perception of Livestock Farming in Oyo State. A case study of Small Ruminant farmers. Proc. 35th Conf., Nig. Sci., for Anim. Prod.14-17 March, University of Ibadan, Ibadan.

Oladeji, J. O., \& Oyesola, O. B. (2008). Small Ruminant Production among Farmers in Iseyin Local Government Area of Oyo State, Nigeria. Journal of Agricultural \& Food Information, 9(3), 256265.

Olaniyan, B.A. (2015). Maize: the panacea for hunger in Nigeria. African Journal of Plant Science, 9(3), 155-174.

Onyeonagu, C.C. \& O.L. Njoku. (2010). Crop residues and agro-industrial by-products use in traditional sheep and goat production in rural communities of Makurdi LGA. Agro -Science Journal of Tropical Agriculture, Food, Environment and Extension, 9(30), 161-169.

Samireddypalle, A., A. Ayantunde, A. Okike, O.J. Babayemi, A.O. Sosina \& A. Duncan. (2014). Assessment of Livestock feed value chain in Ayedire and Atakumosa East local government areas of Osun state. CGIAR Research Program on Integrated Systems for the Humid Tropics. ILRI Technical Report December 2014 www.cgspace.cgiar.org

Steinfeld, H., T. Wassenaar \& S. Jutzi. (2006). Livestock production systems in developing countries: Status, drivers, trends. Rev. Sci. tech off. Int. Epiz., 25(2), 505-156.

Thornton, P.K. \& M. Herrero. (2001). Integrated croplivestock simulation models for scenario analysis and impact assessment. Agricultural Systems, 70, 581-602.

Thornton, P.K., R.L. Kruska., N. Henninger., P.M. Kristjanson., R.S. Reid., F. Atieno., A. Oderoand T. Ndegwa (2002). Mapping Poverty and Livestock in the Developing World. ILRI (International Livestock Research Institute), Nairobi, Kenya

World Bank (2015a). Povcalnet Online analysis tool for global poverty monitoring (available @: HTTP:// iresearch.worldbank.org/PovcalNet/index.htm.) Last accessed July 2015. 


\section{Annex 1: Feed assessment tool - PRA report}

\begin{tabular}{l} 
Name of site/village: \\
Name of sub-district: \\
Name of district: \\
Number of households in survey area (to be considered o household, the \\
dwelling must hove o kitchen): \\
GPS co-ordinate of PRA location: \\
Country: \\
Number of participants present: \\
Date: \\
\hline Start time of PRA:
\end{tabular}

1. General Farming System Description.

Objective: Obtoin o general picture of the forming and livestock system

1.1. What is the typical (or average) farm size ("form size" is considered to be cultivoted lond)? Also consider additional lands that may be leased or shared.

\begin{tabular}{|c|c|}
\hline $\begin{array}{c}\text { agcres, hectares or local units (circle one) } \\
\text { if lacal units whot is the conversion rotio? } \\
1 \text { hectore }=\quad \text { locol units }\end{array}$ \\
\hline
\end{tabular}

1.2. What is the typical (or average) household size? On average, how many people have been living continuously in each household for the past 6 months

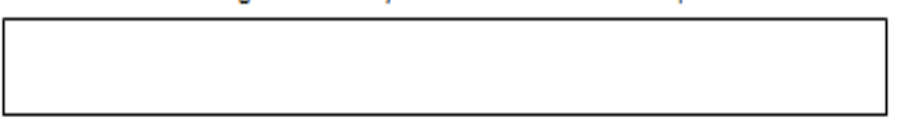

1.3. How does the rainfall pattern vary over a year (on a scale of $0-5$, where $5=$ heovy roinfoll levels and $0=$ no roinfoll)?

\begin{tabular}{|l|l|l|l|l|l|l|l|l|l|l|l|l|}
\hline Month & lan & Feb & March & April & May & Iune & Iuly & Aug & Sept & Oct & Nov & Dec \\
\hline $\begin{array}{l}\text { Rainfall } \\
\text { pattern } \\
\text { (score 0-5) }\end{array}$ & & & & & & & & & & & & \\
\hline
\end{tabular}

1.4. Name the cropping seasons that occur in this area. In which months do the various seasons occur (tick the appropriate boxes in the table below).

\begin{tabular}{|l|l|l|l|l|l|l|l|l|l|l|l|l|}
\hline Name of season & lan & Feb & March & April & May & lune & luly & Aug & Sept & Oct & Nov & Dec \\
\hline 1. & & & & & & & & & & & & \\
\hline 2. & & & & & & & & & & & & \\
\hline 3. & & & & & & & & & & & & \\
\hline
\end{tabular}

1.5. Is irrigation available in the area? What percentage (\%) of household s have access to irrigation?

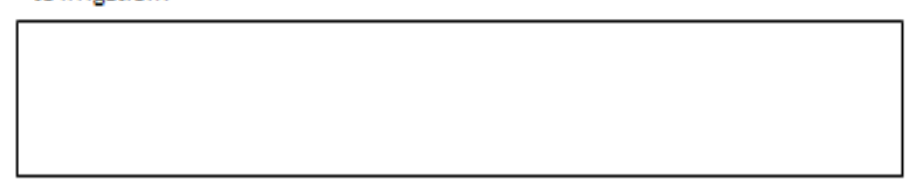

1.6. Is labour readily available throughout the year? When is it most required? How much is it to hire (daily paid) labour? Are many people leaving the farm to work in the city/town or seek education?

Labour availability-
When is it most required? -
Price of (daily-paid) labour -
Are many people leaving the farm for work or education? -
Additional comments:
at livestock are raised within the area? What are the animals mainly used for (eg. 
production of milk for sale, production of milk for household consumption, meat production, draught, manure production etc.)? What gersectage (\$\%lof households. in the areasewn each species? What is the average number of animals per

household?

\begin{tabular}{|c|c|c|c|}
\hline Livestock species & Use & $\begin{array}{c}\text { \% of HH } \\
\text { that own } \\
\text { the species. }\end{array}$ & $\begin{array}{c}\text { Average } \\
\text { number of } \\
\text { animals per } \mathrm{HH}\end{array}$ \\
\hline \multicolumn{4}{|l|}{ Local Dairy cows } \\
\hline \multicolumn{4}{|l|}{ Improved dairy cows } \\
\hline & & & \\
\hline & & & \\
\hline \multicolumn{4}{|l|}{ Draught cattle } \\
\hline \multicolumn{4}{|l|}{ Fattening cattle } \\
\hline \multicolumn{4}{|l|}{ Sheep } \\
\hline \multicolumn{4}{|l|}{ Goats } \\
\hline \multicolumn{4}{|l|}{ Pigs } \\
\hline \multicolumn{4}{|l|}{ Poultry-village } \\
\hline \multicolumn{4}{|l|}{ Poultry-commercial } \\
\hline & & & \\
\hline & & & \\
\hline & & & \\
\hline
\end{tabular}

1.8. Is cash/credit a constraint to crop/livestock production or is it readily available?

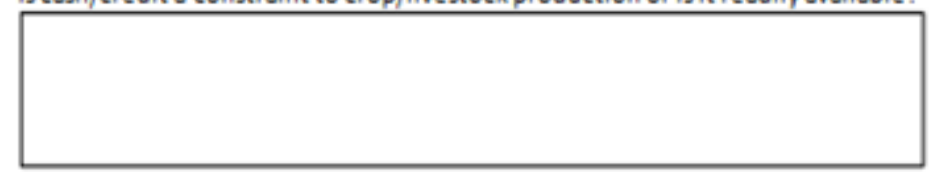

1.9. Is land for cultivation in short supely? Is fallowing practiced? Is land used for more than one crop per year?

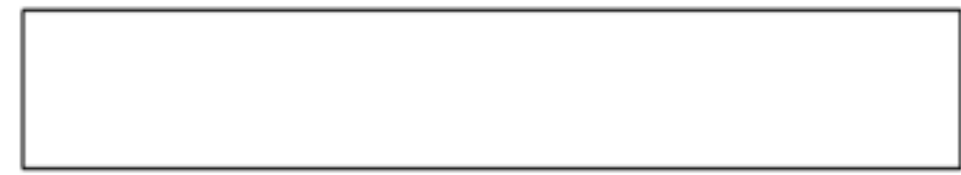

1.10. Are agricultural inputs readily available? Are items such as urea, plastic sheeting, cement, irrigation equipment available in the local market?

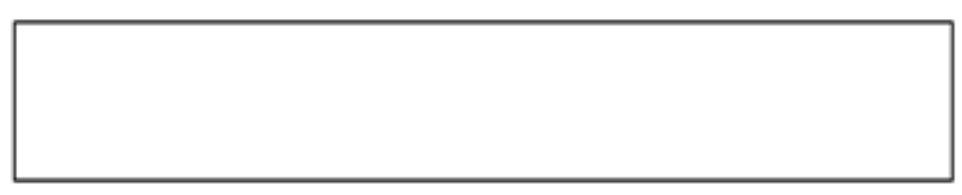

\section{Management of livestock species}

\section{Obiective: Understond how livestock ore monoged within the oreo}

2.1. How are animals in the area managed (including how livestock are housed, the primary style of feeding (ę, stall fed, tethered, open grazing) and the level of feed processing undertaken (eg, Chopping, urea treatment, mixing etc.))? Is there any seasonal variation in management methods? 
Int. J. Agr. Ext. 07 (02) 2019. 177-186

Housing-

Style of feeding (stall fed, tethered, open grazing)-

Feed processing (chopping, urea treatment, mixing etc.)-

Additional comments:
DOI: $10.33687 /$ ijae.007.02.2730

2.2. What veterinary (or animal health) services are available to farmers (including price of treatments and accessibility)?

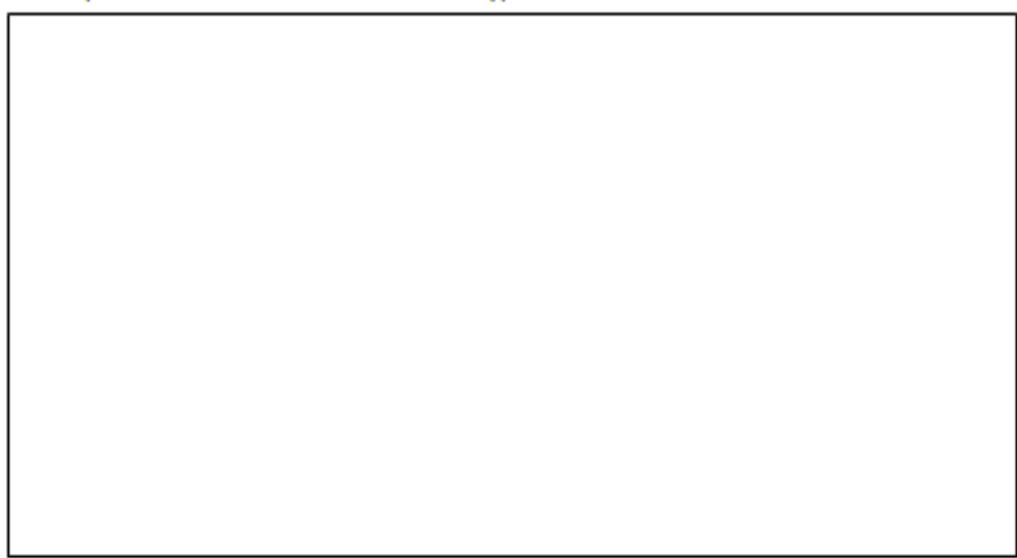

2.3. What methods of livestock reproduction are utilised within the area fincludin availability of Al, price of semen and Al service, rate of repeat services and the price of bull services)?

Availability of $\mathrm{Al}$ -

Price of semen -

Price of Al service -

Rate of repeat services -

Price of bull services -

If bull services are used, are the bulls local or improved breeds?

Additional comments: 
Int. J. Agr. Ext. 07 (02) 2019. 177-186

\section{Problems, issues, opportunities within the livestock system}

Objective: Find out iffeed is likely to be a mojor foctor limiting onimal production, if it is recognized by formers and whot formers see os potentiol solutions.

3.1. List the major problems faced by farmers in the area with reference to livestock production. What do farmers view as the solution to these identified problems?

\begin{tabular}{|l|}
\hline \multicolumn{1}{|c|}{ Main problems } \\
\hline Problem 1 \\
\hline Solution \\
\hline Problem 2 \\
\hline Solution \\
\hline Problem 3 \\
\hline Solution \\
\hline
\end{tabular}

DOI: $10.33687 /$ ijae.007.02.2730

\begin{tabular}{|l|}
\hline Problem 5 \\
\hline Solution \\
\end{tabular}

3.2. Complete pair-wise comparisons for these problems in the table below. For each comparison, record which problem is identified as the more important of the two.

\begin{tabular}{|lll|l|}
\hline \multicolumn{2}{|c|}{ Comparison } & $\begin{array}{c}\text { Which problem is more } \\
\text { important to farmers? }\end{array}$ \\
\hline Problem 1 & $\vee$ & Problem 2 & \\
\hline Problem 1 & $v$ & Problem 3 & \\
\hline Problem 1 & $v$ & Problem 4 & \\
\hline Problem 1 & $v$ & Problem 5 & \\
\hline Problem 2 & $v$ & Problem 3 & \\
\hline Problem 2 & $v$ & Problem 4 & \\
\hline Problem 2 & $v$ & Problem 5 & \\
\hline Problem 3 & $v$ & Problem 4 & \\
\hline Problem 3 & $v$ & Problem 5 & \\
\hline Problem 4 & $v$ & Problem 5 & \\
\hline
\end{tabular}

From the comparison table above, count how many times each problem was rated by the farmers as the most important. The problem with the highest number is considered to be the most important problem limiting animal productivity in the area.

\begin{tabular}{|l|l|l|l|l|l|}
\cline { 2 - 6 } \multicolumn{1}{c|}{} & $\begin{array}{l}\text { Problem } \\
1\end{array}$ & \begin{tabular}{l} 
Problem \\
\multicolumn{1}{c|}{}
\end{tabular} & $\begin{array}{l}\text { Problem } \\
3\end{array}$ & $\begin{array}{l}\text { Problem } \\
4\end{array}$ & $\begin{array}{l}\text { Problem } \\
5\end{array}$ \\
\hline $\begin{array}{l}\text { Number of times the problem was } \\
\text { considered the most important }\end{array}$ & & & & & \\
\hline
\end{tabular}

